\title{
Stenotrophomonas maltophilia outer membrane protein A induces epithelial cell apoptosis via mitochondrial pathways ${ }^{\S}$
}

\author{
Xin Wang ${ }^{1,2}$, Yan Li ${ }^{1}$, Xueping Tang ${ }^{2}$, \\ Xueyi Shang ${ }^{2}$, Zunquan Zhao ${ }^{3}$, \\ Yongqiang Jiang ${ }^{3}$, and Yan $\mathrm{Li}^{2 *}$ \\ ${ }^{1}$ Academy of Military Medical Sciences, Beijing, P. R. China \\ ${ }^{2}$ Department of Critical Care Medicine, 5th Medical Center of PLA \\ General Hospital, Beijing, P. R. China \\ ${ }^{3}$ State Key Laboratory of Pathogen and Biosecurity, Academy of Military \\ Medical Sciences Institute of Microbiology and Epidemiology, Beijing, \\ P. R. China \\ (Received May 4, 2020 / Revised Jul 6, 2020 / Accepted Jul 21, 2020)
}

Stenotrophomonas maltophilia (S. maltophilia) is a common opportunistic pathogen in intensive care units and causes infections most often after surgeries in immune-compromised patients such as those undergoing chemotherapy. Outer membrane protein $\mathrm{A}(\mathrm{OmpA})$ is the most abundant of the outer membrane proteins in S. maltophilia. Previous studies on OmpA usually focus on its interaction with the host cells and its role in vaccine development. However, the impact of OmpA on the virulence of $S$. maltophilia to host cells and the effects on apoptosis remain unclear. In this study, we exposed purified recombinant S. maltophilia OmpA (rOmpA) to HEp-2 cells and investigated the effects of OmpA on epithelial cell apoptosis. Morphologic and flow cytometric analyses revealed that HEp- 2 cells stimulated with rOmpA multiple apoptosis features, including nuclear roundness and pyknosis, chromatin aggregation, and phosphatidylserine eversion. We found that rOmpA regulated the protein levels of Bax and Bcl-xL in HEp-2 cells, leading to changes in mitochondria permeability and the release of cytochrome $c$ and apoptosis-inducing factors into the cytoplasm. These subsequently activate the caspase- $9 /$ caspase- 3 pathway that promote apoptosis. We also observed that rOmpA enhanced the generation of reactive oxygen species and increased intracellular $\mathrm{Ca}^{2+}$ levels in HEp-2 cells. Collectively, our data suggested that rOmpA induced epithelial cells apoptosis via mitochondrial pathways.

Keywords: Stenotrophomonas maltophilia, OmpA, epithelial, apoptosis, mitochondria

\footnotetext{
*For correspondence. E-mail: liyanmdhuxi@163.com; Tel.: +86-10-6694

7371; Fax: +86-10-66947120

${ }^{\varsigma}$ Supplemental material for this article may be found at

http://www.springerlink.com/content/120956.

Copyright (c) 2020, The Microbiological Society of Korea
}

\section{Introduction}

Stenotrophomonas maltophilia (S. maltophilia) is a non-fermenting and obligately aerobic Gram-negative bacteria that is widely distributed in nature and resides in the human respiratory tract and feces. It has been well recognised as a common opportunistic pathogen in the clinic (Lee et al., 2014; Li et al., 2017a). Recently, it has been reported that the prevalence of $S$. maltophilia infection in intensive care units has been increasing continuously (Chang et al., 2012). Outer membrane protein $\mathrm{A}(\mathrm{OmpA})$ is a unique protein on the surface or embedded in the cell membrane of Gram-negative bacteria and is closely associated with the development of bacterial infection and the activation of host immune response (March et al., 2011; Li et al., 2019). Previous studies have suggested that the pathogenicity of $S$. maltophilia may be associated with OmpA-medicated adhesion to the host cells and the consequent stimulation of host cell apoptosis (Gaddy et al., 2009; Zhang et al., 2010).

The impact of OmpA on host cell apoptosis varies greatly depending on the differences in the secondary structure of OmpA. Previous studies found that A. baumannii OmpA induces Hela cells autophagy by activating the MAPK/JNK signalling pathway (An et al., 2019). Similarly, researchers have reported that A. baumannii OmpA stimulates epithelial and dendritic cell apoptosis (Choi et al., 2005, 2008; Lee et al., 2010) and have found that Leptospirosis Loa22, a member of the OmpA family, triggers apoptosis of A549 cells (Wu et al., 2011). In contrast to these findings, E. coli K1 OmpA inhibits host cell apoptosis (Sukumaran et al., 2004).

The role of mitochondria in apoptosis has been well-described. A key event in the mitochondrial pathway to apoptosis is the permeabilisation of the mitochondrial outer membrane. The outer mitochondrial membrane may be affected by adverse factors, leading to the leakage of mitochondrial membrane proteins such as cytochrome $\mathrm{c}$ and apoptosis-inducing factor into the cytoplasm. The release of cytochrome c activates caspase- 9 , which in turn activates caspase- 3 and initiates apoptosis (Elmore, 2007; Pistritto et al., 2016). Bcl-2 family proteins include pro-apoptotic proteins and pro-survival proteins that promote or prevent apoptosis by govering permeabilisation of the outer mitochondrial membrane. The pro-survival proteins (Bcl-2 and Bcl-xL) prevent the translocation of cytochrome $\mathrm{c}$ from the mitochondria while the pro-apopotic proteins (Bax and Bak) enhance cytochrome $\mathrm{c}$ release (Birkinshaw and Czabotar, 2017). In addition, prosurvival proteins surpress the formation of reactive oxygen species (ROS) and the generation of $\mathrm{Ca}^{2+}$ (Zhao et al., 2016). Therefore, we investigated the role of mitochondrial pathways in S. maltophilia OmpA-induced apoptosis in this study. 
Respiratory tract infections are a major cause of morbidity and mortality in intensive care units and most commonly involve the lower airways, which are preceded by bacterial colonisation of the upper airways. Similar to other opportunistic pathogens, S. maltophilia invasion of the upper respiratory tract promotes bacterial colonisation. Upper respiratory tract colonisation not only causes disease, but also drives the evolution of these opportunistic pathogens (Siegel and Weiser, 2015). Therefore, we employed human laryngeal epithelial HEp-2 cells to investigated the molecular mechanisms of apoptosis induced by $S$. maltophilia OmpA. HEp-2 cell is derived from epithelial laryngeal carcinoma cells, which is widely used in studies evaluating cellular proliferation, migration, and apoptosis (Lopes et al., 2020).

\section{Materials and Methods}

\section{Bacterial strains}

The bacteria strain S. maltophilia K279a was used in this study due to the availability of the entire genome sequence, which is representative of this species. The bacteria were grown in lysogeny broth (LB) and kanamycin-resistant Escherichia coli (E. coli) BL21 (DE3) was used for recombinant protein production.

\section{Regents and antibodies}

Alexa Fluor ${ }^{\circledR} 647$ Protein Labeling Kit was purchased from Thermo Fisher Scientific. Staurosporine (ST) was purchased from ChengZhu Biotechnology. Annexin V conjugated to APC, prodidium Iodide (PI) staining solution, and 10× Annexin V Binding Buffer were purchased from BD Biosciences. TMREMitochondrial Membrane Potential Assay Kit was purchased from Abcam. Mitochondria/Cytosol Fraction Kit was purchased from BioVision. ROS assay kit was purchased from Beyotime. Fluo-3, AM molecular probe was purchased from Solarbio Biotechnology. DAPI was purchased from Beyotime Biotechnology. Purified His-tagged recombinant S. maltophilia OmpW (rOmpW) and rabbit anti-rOmpA serum were obtained from the previous study (Xu et al., 2018; Li et al., 2019). Bax (sc-20067), Bcl-xL (sc-136207), cytochrome c (sc13156), AIF (sc-55519), caspase-3 (sc-7272), PARP (sc-53643), and $\beta$-actin (sc-81178) antibodies were purchased from Santa Cruz. Caspase-9 (9502s) antibody was purchased from Cell Signaling Technology. Goat IRDye680RD-labelled anti-rabbit IgG antibody was purchased from LI-COR Biosciences.

\section{Preparation of S. maltophilia strain K279a outer membrane proteins}

S. maltophilia K279a was inoculated in $5 \mathrm{ml} \mathrm{LB}$ medium, which was cultured overnight at $37^{\circ} \mathrm{C}$ with constant shaking. On the second day, it was transferred to $500 \mathrm{ml} \mathrm{LB}$ medium at 1:100 for expansion to an optical density (OD) $600 \mathrm{~nm}$ of 1.0 and subsequently sonicated and centrifuged at 3,000 $\times g$ for $20 \mathrm{~min}$ to remove unlysed bacteria. The supernatant containing cytoplasmic and extracellular bacterial components was centrifuged at $100,000 \times g$ at $4^{\circ} \mathrm{C}$ for $1 \mathrm{~h}$. The supernatant with cytoplasmic components was removed. The pellet was then resuspended with $10 \mathrm{ml}$ Tris-Mg buffer (10 mM Tris-
$\mathrm{HCl}$ and $5 \mathrm{mM} \mathrm{MgCl}_{2} ; \mathrm{pH} 7.3$ ) containing $2 \%$ sodium lauryl sulphate and incubated in the chamber for 20-30 min at room temperature to solubilise the inner membrane. Then the suspension was centrifuged at $100,000 \times g$ at $4^{\circ} \mathrm{C}$ for $1 \mathrm{~h}$. The supernatant was fully removed and the precipitate containing the outer membrane proteins was resuspended with $0.1-0.2 \mathrm{ml} \mathrm{ddH_{2 }} \mathrm{O}$ according to the precipitation volume.

\section{Preparation of recombinant OmpA}

Escherichia coli $\mathrm{BL} 21$ were cultured in $\mathrm{LB}$ at $37^{\circ} \mathrm{C}$ overnight and harvested. On the next day, the bacteria were grown in $\mathrm{LB}$ medium supplemented with $50 \mu \mathrm{g} / \mathrm{ml}$ kanamycin at $37^{\circ} \mathrm{C}$ until an $\mathrm{OD}_{600} \mathrm{~nm}$ of $0.4-0.6$. rOmpA expression was induced by $1 \mathrm{mM}$ isopropyl- $\beta$-D-thiogalactopyranoside (IPTG) (Sigma) at $30^{\circ} \mathrm{C}$ for $6 \mathrm{~h}$. The bacteria were centrifugated at $12,000 \mathrm{rpm}$ at $4^{\circ} \mathrm{C}$ for $20 \mathrm{~min}$. Subsequently, the supernatant was collected and purified by a HiTrap Chelating HP column (GE Healthcare). Detection of rOmpA expression was performed by western blot.

\section{Cell culture}

HEp-2 cells were grown in RAMI 1,640 medium (Gibco) supplemented with $10 \%$ foetal bovine serum (HyClone), 2 $\mathrm{mM}$ L-glutamine, 1,000 U/ml penicillin $\mathrm{G}$, and $50 \mu \mathrm{g} / \mathrm{ml}$ streptomycin at $37^{\circ} \mathrm{C}$ in a $5 \% \mathrm{CO}_{2}$ incubator. Confluent growth was obtained in $100 \mathrm{~mm}$-diameter dishes and the cells were routinely passaged every 3 days.

\section{Fluorescent protein labelling}

Protein labelling was performed using an Alexa Fluor ${ }^{\circledR} 647$ Protein Labeling Kit (Thermo Fischer Scientific). We added $50 \mu \mathrm{l} 1 \mathrm{M}$ sodium bicarbonate $(\mathrm{pH} 8.3)$ to $0.5 \mathrm{ml} 1 \mathrm{mg} / \mathrm{ml}$ rOmpA protein solution and $1 \mathrm{mg} / \mathrm{ml} \mathrm{BSA}$ and $1 \mathrm{mg} / \mathrm{ml}$ rOmpW were used as controls. Alexa Fluor ${ }^{\circledR} 647$ dye was warmed to room temperature and the protein solution was added in a 20:1 ratio. The mixture was covered and stirred for $1 \mathrm{~h}$ at room temperature. HEp-2 cells were seeded in 6well culture dishes at a density of $1 \times 10^{5}$ cells/well. After $48 \mathrm{~h}$ of incubation, the cells were treated with $30 \mu \mathrm{g} / \mathrm{ml}$ labelled BSA, $10 \mu \mathrm{g} / \mathrm{ml}$ labelled rOmpA, $30 \mu \mathrm{g} / \mathrm{ml}$ labelled rOmpA, or $30 \mu \mathrm{g} / \mathrm{ml}$ labelled rOmpW for $4 \mathrm{~h}$. Then, the cells were washed three times in PBS and centrifuged at $1,000 \times g$ for $5 \mathrm{~min}$. The samples were resuspended in PBS and fluorescence was detected by an Accuri-C6-Plus flow cytometer (BD Biosciences). Data were analysed using FlowJo.

\section{Confocal microscopy}

HEp-2 cells were seeded in 4-well chamber slide with removable wells (Thermo Fisher Scientific) at a density $5 \times 10^{4}$ cells per well. After $48 \mathrm{~h}$ of incubation, the cells were treated with PBS, $0.1 \mu \mathrm{M} \mathrm{ST}, 10 \mu \mathrm{g} / \mathrm{ml} \mathrm{rOmpA}, 30 \mu \mathrm{g} / \mathrm{ml} \mathrm{rOmpA}$, or $30 \mu \mathrm{g} / \mathrm{ml}$ heat-inactivated $\mathrm{rOmpA}$. The lower concentration of ST induces specific cell cycle effects and blocks cells in the G1 or G2 phase, thereby induce apoptosis. We used 0.1 $\mu \mathrm{M}$ ST as the apoptosis-positive control in our study. Nuclear changes such as chromatin condensation and nuclear fragmentation were analysed by staining with DAPI (Molecular Probes). After the cells were treated for the indicated times, 
they were fixed in 3\% paraformaldehyde and stained with $10 \mathrm{mg} / \mathrm{ml}$ DAPI for $10 \mathrm{~min}$ in the dark. The stained cells were observed using a confocal microscope (Olympus).

\section{Transmission electron microscopy}

HEp-2 cells were seeded in 6-well culture dishes at a density of $1 \times 10^{5}$ cells/well. After $48 \mathrm{~h}$ of incubation, we treated the cells with PBS, $0.1 \mu \mathrm{M} \mathrm{ST}$, or $30 \mu \mathrm{g} / \mathrm{ml} \mathrm{rOmpA}$. After the cells were treated for the indicated times and washed three times in PBS, the cells were centrifuged at $3,000 \times g$ for $5 \mathrm{~min}$ and fixed with $2.5 \%$ glutaraldehyde at $4^{\circ} \mathrm{C}$. Then the cells were washed three times in PBS, and fixed for $1.5 \mathrm{~h}$ with $1 \%$ osmium tetroxide at room temperature. The samples were dehydrated in a series of ethanol concentrations and embedded in in epoxy resin. Sections of $60 \mathrm{~nm}$ thickness were obtained using a microtome (Leica) and stained with uranyl acetate and lead citrate. The sections were analysed using an HT7000 transmission electron microscope (Hitachi).

\section{Apoptosis}

HEp- 2 cells were seeded in 12-well culture dishes at a density of $5 \times 10^{4}$ cells/well. After $48 \mathrm{~h}$ of incubation, the cells were treated with PBS, $0.1 \mu \mathrm{M}$ ST, $10 \mu \mathrm{g} / \mathrm{ml} \mathrm{rOmpA}, 30 \mu \mathrm{g} / \mathrm{ml}$ rOmpA, or $30 \mu \mathrm{g} / \mathrm{ml}$ heat-inactivated rOmpA. After $8 \mathrm{~h}$, the cells were washed three times in PBS and centrifuged at 1,000 rpm for $5 \mathrm{~min}$ and resuspended in $400 \mu \mathrm{l}$ binding buffer (BD Biosciences). We added $5 \mu \mathrm{l}$ annexin V-APC and PI to each sample by gentle mixing and incubated the samples for 30 min in the dark at room temperature. Fluorescence was detected by flow cytometry and analysed using FlowJo.

\section{Mitochondrial transmembrane potential}

HEp-2 cells were seeded in 12-well culture dishes at a density of $5 \times 10^{4}$ cells/well. After $48 \mathrm{~h}$ of incubation, the cells were treated with PBS, $0.1 \mu \mathrm{M}$ ST, $10 \mu \mathrm{g} / \mathrm{ml} \mathrm{rOmpA}, 30 \mu \mathrm{g} / \mathrm{ml}$ rOmpA, or $30 \mu \mathrm{g} / \mathrm{ml}$ heat-inactivated rOmpA. After $8 \mathrm{~h}$, the cells were washed three times in PBS and centrifuged at 1,000 rpm for $5 \mathrm{~min}$. The positive depolarisation control group was exposed to $50 \mu \mathrm{M}$ carbonyl cyanide-4-(trifluoromethoxy) phenylhydrazone (FCCP) and incubated at $37^{\circ} \mathrm{C}$ for $10 \mathrm{~min}$ in the dark and all samples were stained with $100 \mathrm{nM}$ tetramethylrhodamine ethyl ester (TMRE) and incubated at $37^{\circ} \mathrm{C}$ for $10 \mathrm{~min}$ in the dark. Analysis of mitochondrial membrane potential was performed using flow cytometry and data was analysed by FlowJo.

\section{Subcellular fractionation}

HEp-2 cells were seeded in 6-well culture dishes at a density $1 \times 10^{5}$ cells/well. After $48 \mathrm{~h}$ of incubation, the cells were treated with PBS, $0.1 \mu \mathrm{M} \mathrm{ST}, 10 \mu \mathrm{g} / \mathrm{ml} \mathrm{rOmpA}, 30 \mu \mathrm{g} / \mathrm{ml}$ rOmpA, or $30 \mu \mathrm{g} / \mathrm{ml}$ heat-inactivated rOmpA. After $8 \mathrm{~h}$, the cells were washed three times in PBS and the mitochondrial fraction was isolated using a Mitochondria/Cytosol Fractionation kit (BioVision) according to the manufacturer's instructions. The samples were separated by electrophoresis with $12 \%$ SDS-PAGE and western blot was performed.

\section{Western blot}

HEp-2 cells were seeded in 6-well culture dishes at a density of $1 \times 10^{5}$ cells/well. After $48 \mathrm{~h}$ of incubation, the cells were treated with PBS, $0.1 \mu \mathrm{M}$ ST, $10 \mu \mathrm{g} / \mathrm{ml} \mathrm{rOmpA}, 30 \mu \mathrm{g} / \mathrm{ml}$ rOmpA, or $30 \mu \mathrm{g} / \mathrm{ml}$ heat-inactivated rOmpA. After $8 \mathrm{~h}$, the cells were washed three times in PBS and lysed with modified RIPA buffer (1.0\% NP-40, 1.0\% sodium deoxycholate, $150 \mathrm{nM} \mathrm{NaCl}, 10 \mathrm{mM}$ Tris-HCl; pH 7.5, $5.0 \mathrm{mM}$ sodium pyrophosphate, $1.0 \mathrm{mM} \mathrm{NaSO}_{4}, 5.0 \mathrm{mM} \mathrm{NaF}, 10 \mathrm{mM}$ leupeptin, and $0.1 \mathrm{mM}$ phenylmethylsulfonyl fluoride) on ice. The cell lysates were centrifuged at $10,000 \times g$ for $10 \mathrm{~min}$ and the protein concentration of each sample was determined by Bradford assay. Electrophoresis was performed on 12\% SDSPAGE gels and the proteins were transferred onto $0.45 \mu \mathrm{m}$ nitrocellulose membranes (Merck Milipore). After blocking with $5 \%$ skimmed milk powder at $25^{\circ} \mathrm{C}$ for $1 \mathrm{~h}$, the membranes were incubated overnight with the corresponding primary antibody at $4^{\circ} \mathrm{C}$ followed by washing three times for 10 min with TBST buffer. Subsequently, we incubated the membranes with 1:8,000 goat IRDye680RD-labelled antirabbit IgG antibody at room temperature for $1 \mathrm{~h}$ and washed them four times with TBST for $5 \mathrm{~min}$ in the dark. Protein expression was detected by an Odyssey ${ }^{\circledR}$ CLx (LI-COR Biosciences).

\section{Intracellular ROS accumulation}

Intracellular ROS were fluorometrically estimated using the oxidation-sensitive fluorescent probes 5,6-carboxy-2 ${ }^{\prime}, 7^{\prime}$-dichlorofluorescein-diacetate (DCFH-DA). HEp-2 cells seeded in 12 -well culture dishes at a density of $5 \times 10^{4}$ cells/well. After $48 \mathrm{~h}$ of incubation, the cells were treated with PBS, $0.1 \mu \mathrm{M}$ ST, $10 \mu \mathrm{g} / \mathrm{ml} \mathrm{rOmpA,} 30 \mu \mathrm{g} / \mathrm{ml} \mathrm{rOmpA}$, or $30 \mu \mathrm{g} / \mathrm{ml}$ heat-inactivated rOmpA. After $8 \mathrm{~h}$, the cells were washed three times in $5 \mathrm{mM}$ HEPES-buffered saline and incubated for $15 \mathrm{~min}$ in HEPES-buffered saline with $10 \mu \mathrm{M}$ DCFH-DA. The samples were analysed by a SpectraMax i3 automatic microplate reader (Molecular Device).

\section{Intracellular $\mathrm{Ca}^{2+}$}

HEp-2 cells were seeded in 12-well culture dishes at a density of $5 \times 10^{4}$ cells/well. After $48 \mathrm{~h}$ of incubation, the cells were treated with PBS, $0.1 \mu \mathrm{M} \mathrm{ST}, 10 \mu \mathrm{g} / \mathrm{ml} \mathrm{rOmpA}, 30 \mu \mathrm{g} / \mathrm{ml}$ rOmpA, or $30 \mu \mathrm{g} / \mathrm{ml}$ heat-inactivated rOmpA. After $8 \mathrm{~h}$, the cells were washed three times in PBS and stained with $5 \mu \mathrm{M}$ Fluo-3/AM (Molecular Probes) at $37^{\circ} \mathrm{C}$ for $20 \mathrm{~min}$. Then, the cells were washed in HEPES-buffered saline and incubated for a further $30 \mathrm{~min}$ at $37^{\circ} \mathrm{C}$. The samples were analysed by an automatic microplate reader. To measure intracellular $\mathrm{Ca}^{2+}$, the cells incubated with Fluo-3 AM were excited at $485 \mathrm{~nm}$ and fluorescence was detected with a 530 $\mathrm{nm}$ emission filter.

\section{Statistical analysis}

Prism 5 (GraphPad) was used for statistical analysis. The differences between the treatment groups were compared by Dunnett's multiple comparisons test. The results were obtained from at least three independent experiments and $p<$ 0.05 was considered statistically significant. 


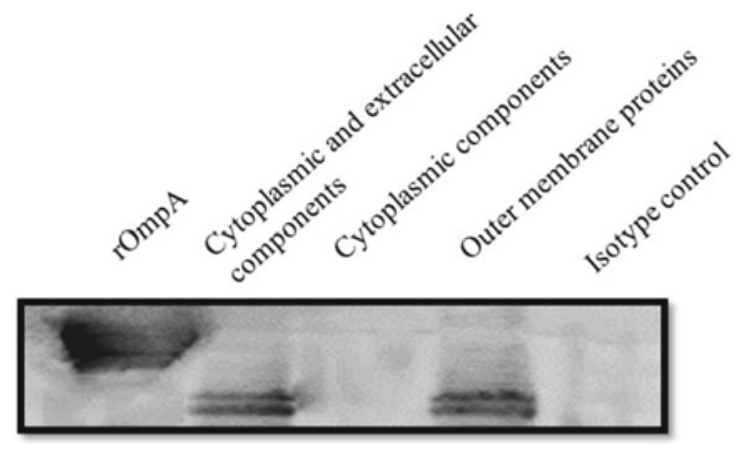

Fig. 1. Identification of rOmpA by western blot. The purified rOmpA, cytoplasmic and extracellular components, cytoplasmic components, outer membrane proteins were resolved on 12\% SDS-PAGE gel and immunoblotted with purified rabbit anti-rOmpA serum. Purified rabbit anti-rOmpA serum was used as the primary antibody and goat IRDye680RD-labelled anti-rabbit IgG antibody was used as the secondary antibody. Purified Histagged rOmpW was used as the isotype control.

\section{Results}

\section{Identification of recombinant S. maltophilia OmpA}

We developed the His-tagged rOmpA in our previous study (Xu et al., 2018; Li et al., 2019). The recombinant plasmid expressing S. maltophilia K279a OmpA was transformed into E. coli BL21, which was cultured and induced by IPTG. rOmpA

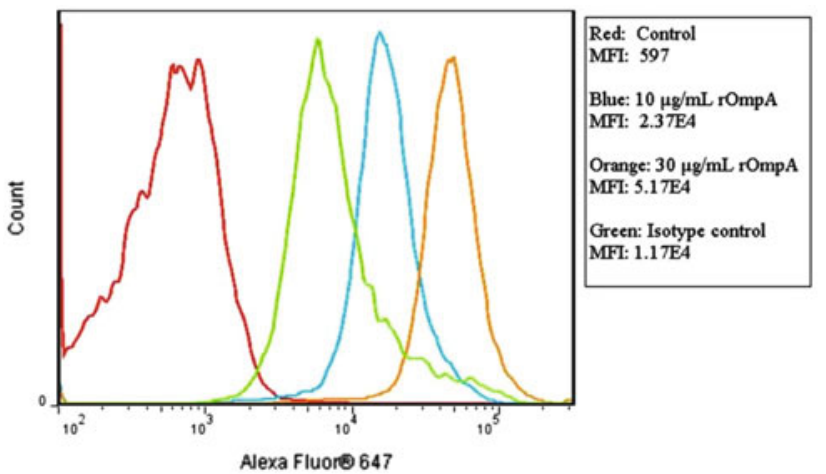

Fig. 2. Flow cytometry analysis of adhesion of rOmpA to HEp-2 cells. Alexa Fluor 647 dye molecules was used to label rOmpA, which attaches to proteins at high molar ratios without significant self-quenching. BSA was used as the control and purified His-tagged rOmpW was used as the isotype control. The HEp-2 cells were incubated with Alexa Fluor ${ }^{\mathbb{R}} 647$ labelled rOmpA for $4 \mathrm{~h}$. The MFI of Alexa Fluor ${ }^{\circledR} 647$ reflected adhesion of labelled proteins to HEp-2 cells.

was purified with a HiTrap chelating HP column (GE Healthcare) according to the manufacturer's instructions and analysed by western blot. We found that purified rabbit antirOmpA serum reacted with both rOmpA and S. maltophilia K279a outer membrane proteins (Fig. 1).
(A)

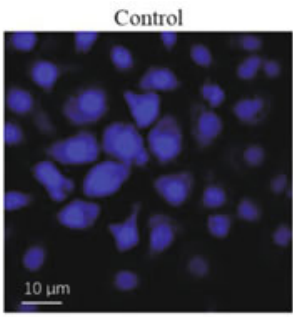

$30 \mu \mathrm{g} / \mathrm{mL}$ rOmpA

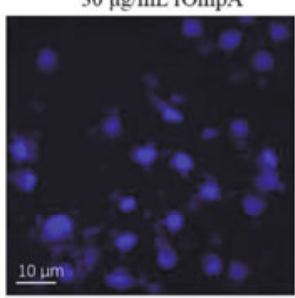

$0.1 \mu \mathrm{M} \mathrm{ST}$

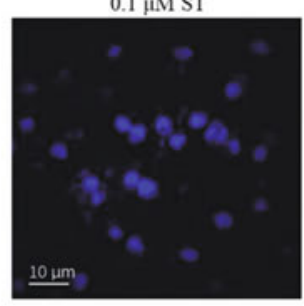

Inactivated rOmpA

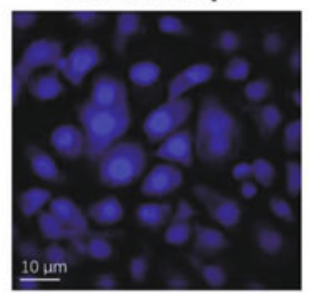

$10 \mu \mathrm{g} / \mathrm{mL}$ rOmpA

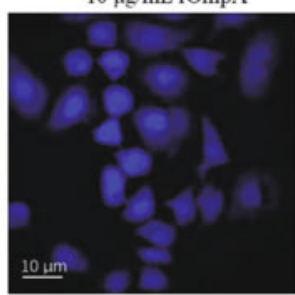

Fig. 3. Detection of nuclear and morphological changes by confocal and transmission electron microscopy. (A) DAPI staining showed nuclear changes of HEp-2 cells exposed to rOmpA for $8 \mathrm{~h}$ (40× magnification). (B) Transmission electron microscope images of HEp-2 cells undergoing apoptosis. White arrow indicate chromatin condensation. Magnifications: a, 8,000×; b, 12,000×; c, $10,000 \times$.
(B)

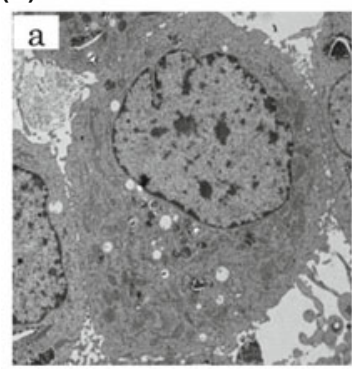

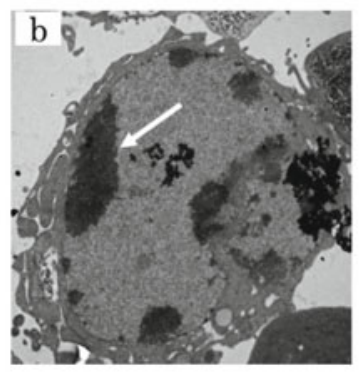

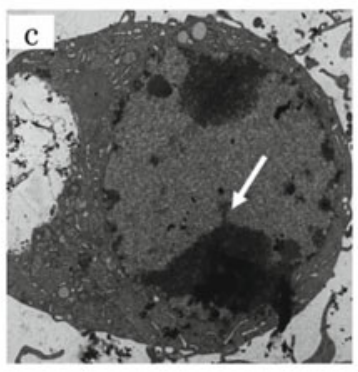




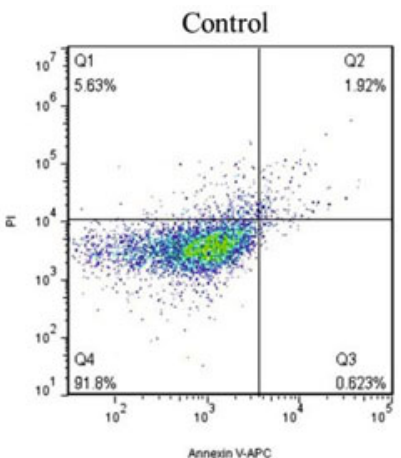

$30 \mu \mathrm{g} / \mathrm{mL}$ rOmpA

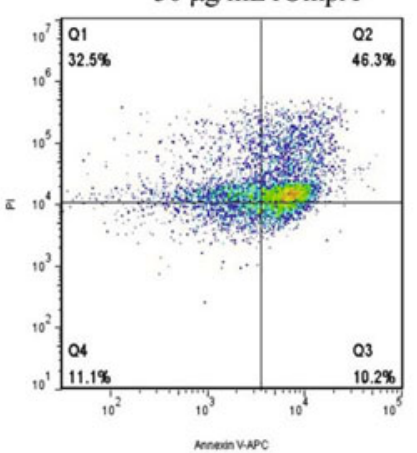

$0.1 \mu \mathrm{M} \mathrm{ST}$

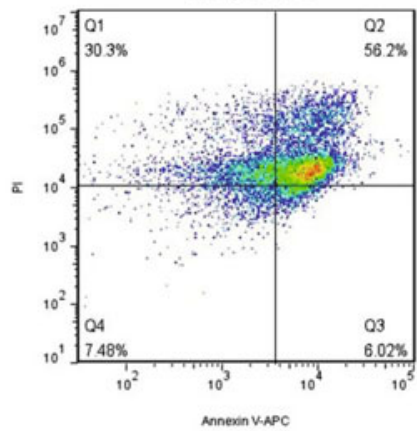

Inactivated rOmpA

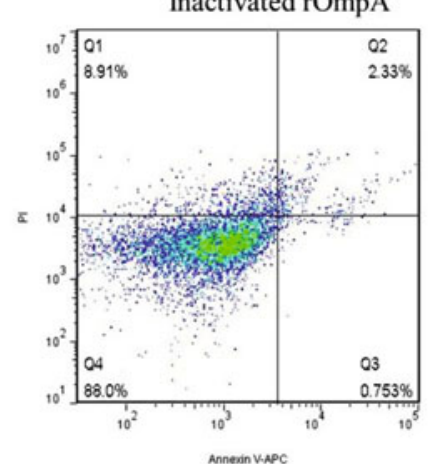

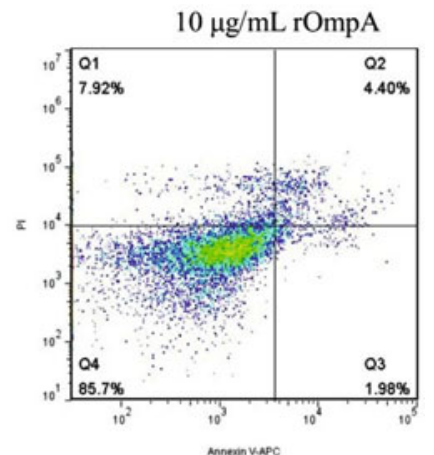

Isotype control

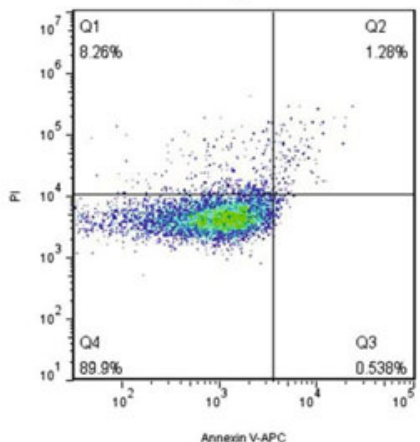

Fig. 4. Flow cytometric analysis of HEp-2 cells apoptosis by annexin-V/PI. HEp-2 cells were treated with $10 \mu \mathrm{g} / \mathrm{ml} \mathrm{rOmpA} \mathrm{or} 30 \mu \mathrm{g} / \mathrm{ml} \mathrm{rOmpA}$ for $8 \mathrm{~h}$ and stained with annexin V-APC and PI. The horizontal axis represents annexin V-APC fluorescence intensity and the vertical axis represents PI fluorescence intensity. Positive annexin V-APC fluorescence indicates apoptosis while positive PI fluorescence indicates cell necrosis. The apoptotic cell populations (upper and lower right quadrants) were analysed and compared. Purified His-tagged rOmpW was used as the isotype control. The results are from one representative experiment of three independent experiments.

\section{The adhesion of rOmpA to HEp-2 cells}

OmpA proteins have important pathogenic roles including bacterial adhesion, invasion, and intracellular survival. Namba et al. (2008) reported that OmpA is involved in adhesion of Aeromonas veronii to host cells and Shin et al. (2005) found that E. coli OmpA adheres to human brain microvascular endothelial cells. To assess the adhesion of rOmpA to HEp-2 cells, we exposed HEp-2 cells to rOmpA labelled with Alexa Fluor $^{\circledR} 647$ and analysed the fluorescence by flow cytometry. The mean fluorescence intensity (MFI) of Alexa Fluor ${ }^{\circledR} 647$ represented the adhesion to HEp- 2 cells. We observed that the MFI of the $10 \mu \mathrm{g} / \mathrm{ml}$ and $30 \mu \mathrm{g} / \mathrm{ml} \mathrm{rOmpA}$ groups were $2.37 \mathrm{E} 4$ and 5.17E4, respectively, compared with an MFI of 597 in the control group. The MFI of the $30 \mu \mathrm{g} / \mathrm{ml} \mathrm{rOmpA}$ group was significantly higher than the control group, suggesting that rOmpA adhered to HEp-2 cells (Fig. 2). Besides, we also found mitochondrial localisation of rOmpA in HEp-2 cells (Supplementary data Fig. S1).

\section{rOmpA induced HEp-2 cells apoptosis}

Apoptotic cells are characterised by reduced cell size, nuclear condensation, nucleolus fragmentation, increased chromatin density, concentrated cytoplasm, and increased organelle density (Henry et al., 2013; Atale et al., 2014). We tested the impact of different concentration of rOmpA $(10 \mu \mathrm{g} / \mathrm{ml}$ and 30 $\mu \mathrm{g} / \mathrm{ml}$ ) on HEp-2 cell apoptosis. We used $0.1 \mu \mathrm{M}$ ST to promote HEp-2 cell apoptosis as a positive control, bacteria- free PBS as a negative control, and $30 \mu \mathrm{g} / \mathrm{ml}$ heat-inactivated rOmpA as another negative control to exclude the influence of LPS on the experiment. Cellular morphology was observed by confocal microscopy and nuclei were stained with DAPI. After $8 \mathrm{~h}$ of treatment, nucleus roundness and pyknosis became apparent in the $30 \mu \mathrm{g} / \mathrm{ml} \mathrm{rOmpA}$ group and the $0.1 \mu \mathrm{M}$

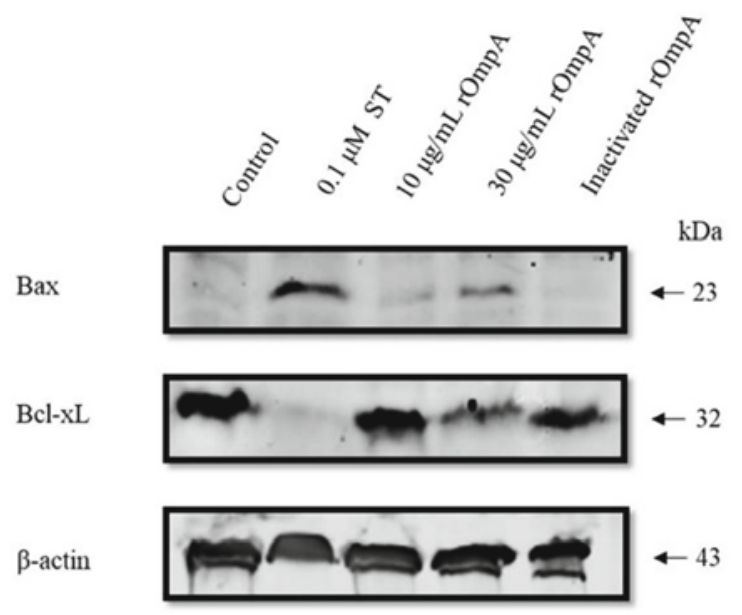

Fig. 5. Impact of rOmpA on Bax and Bcl-xL protein expression in HEp-2 cells by western blot. The cell lysates were resolved on $12 \%$ SDS-PAGE gel and immunoblotted with anti-Bax and anti-Bcl-xL antibody. The results are from one representative experiment of three independent experiments. 
ST group. In comparison, HEp-2 cells exposed to $10 \mu \mathrm{g} / \mathrm{ml}$ rOmpA showed some degree of nucleolysis (Fig. 3A). Transmission electron microscopy revealed that chromatin condensation appeared in the nucleus after $8 \mathrm{~h}$ of $0.1 \mu \mathrm{M}$ ST or $30 \mu \mathrm{g} / \mathrm{ml} \mathrm{rOmpA}$ treatment. These typical apoptotic characteristics supported that rOmpA induced HEp-2 cell apoptosis (Fig. 3B).

To further verify that rOmpA can induce HEp-2 cell apoptosis, the apoptotic and necrotic cell populations were analyzed by flow cytometry using annexin V/PI staining. Phosphatidylserine (PS) is located in the inner cell membrane under physiological conditions. PS externalization occurs in early apoptotic cells, which results in a positive stain for annexin $\mathrm{V}$ whereas living cells remain annexin $\mathrm{V}$ negative. Although annexin $\mathrm{V}$ can be used to detect apoptosis, necrotic cells also become annexin $\mathrm{V}$-positive as annexin $\mathrm{V}$ binds to internal PS. However, combination with PI double-labelling allows for further distinction between necrotic (annexin $\mathrm{V}+\mathrm{l}$ $\mathrm{PI}+$ ) and early apoptotic (annexin V+/PI-) cells (Henry et al., 2013; Wallberg et al., 2016). In this study, annexin V-APC and PI dye were used in flow cytometric analyses and detected rOmpA-induced HEp-2 cell apoptosis (Fig. 4). Speci-
(A)
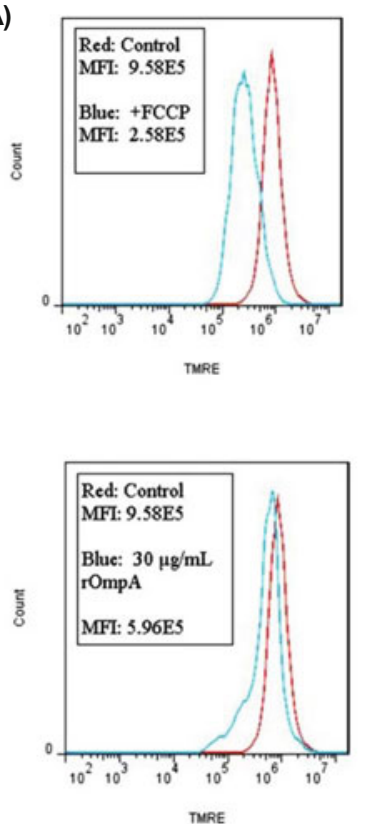

㞼
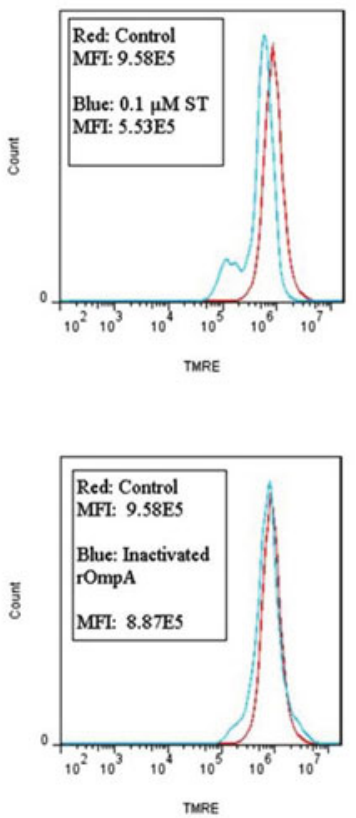

䒝

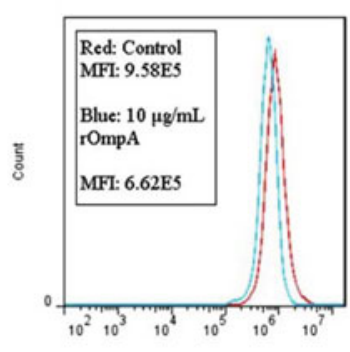

TMRE

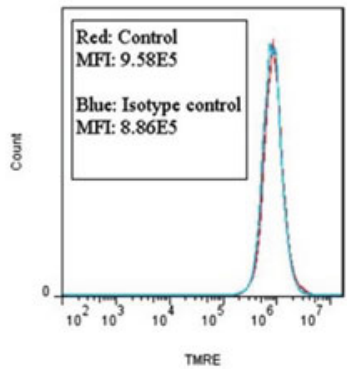

Fig. 6. Changes in mitochondrial membrane permeability of HEp- 2 cells induced by rOmpA. (A) Flow cytometric histogram plots of HEp-2 cells stained with $100 \mathrm{nM}$ TMRE. FCCP was employed as a positive depolarisation control. Purified His-tagged recombinant rOmpW was used as the isotype control. The red line represents the control group and the blue line in each histogram respectively represents the positive depolarisation control group, the $0.1 \mu \mathrm{M}$ ST group, the $10 \mu \mathrm{g} / \mathrm{ml}$ rOmpA group, the $30 \mu \mathrm{g} / \mathrm{ml}$ rOmpA group, the heated-inactivated rOmpA group, and the isotype control group. MFI lower than the control indicates mitochondrial membrane potential depolarisation. (B) Western blot of AIF and cytochrome c. Mitochondrial fractions and cytosolic fractions were resolved on $12 \%$ SDS-PAGE gels and immunoblotted with anti-AIF and anti-cytochrome $c$ antibody. The results are from one representative experiment of three independent experiments.
(B)

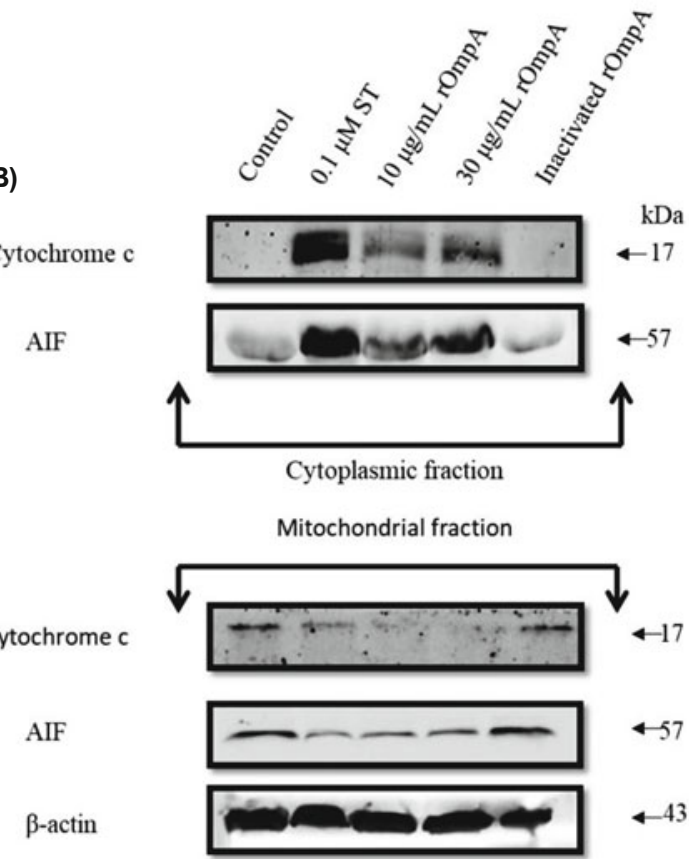


fically, few apoptotic cells were detected in the control group and heat-inactivated rOmpA group, in which the proportions of early and late apoptotic cells were $0.623 \%$ and $1.92 \%$ in the control group and $0.753 \%$ and $2.33 \%$ in the heat-inactivated rOmpA group. The number of apoptotic cells was increased after exposure to $0.1 \mu \mathrm{M} \mathrm{ST}$ and $30 \mu \mathrm{g} / \mathrm{ml} \mathrm{rOmpA}$ group with early and late apoptotic cells proportions of $6.02 \%$ and $56.2 \%$ in the $0.1 \mu \mathrm{M}$ ST group and $10.2 \%$ and $46.3 \%$ in the $30 \mu \mathrm{g} / \mathrm{ml} \mathrm{rOmpA}$ group. Furthermore, the proportions of early and late apoptotic cells were $1.98 \%$ and $4.4 \%$ in the $10 \mu \mathrm{g} / \mathrm{ml} \mathrm{rOmpA}$ group (Fig. 4). These data suggested that $30 \mu \mathrm{g} / \mathrm{ml} \mathrm{rOmpA}$ induced HEp-2 cells apoptosis.

\section{rOmpA regulated the expression of Bax and Bcl-xL in HEp-2 cells}

Apoptotic pathways include internal mitochondrial apoptosis, death receptor-mediated external apoptosis, and lysosomal apoptosis. Previous studies on Acinetobacter baumannii OmpA-induced apoptosis showed that epithelial cell apoptosis was mediated by the mitochondrial pathway (Choi et al., 2005; Lee et al., 2010). Activation of mitochondrial apoptosis is associated with upregulation of the pro-apoptotic proteins such as Bax and Bak and downregulation of pro-survival proteins including Bcl-xL and Bcl-2 (Zhou et al., 2011; Birkinshaw and Czabotar, 2017). In the current study, HEp-2 cells treated with $0.1 \mu \mathrm{M}$ ST and $30 \mu \mathrm{g} / \mathrm{ml} \mathrm{rOmpA}$ showed significantly higher Bax protein levels than the control group. In contrast, Bax in the heat-inactivated rOmpA group did not significantly differ from the control group (Fig. 5). Exposure to $10 \mu \mathrm{g} / \mathrm{ml} \mathrm{rOmpA}$ also increased Bax protein levels. Contrary to $\mathrm{Bax}, \mathrm{Bcl}-\mathrm{xL}$ protein levels were reduced by $\mathrm{rOmpA}$ and ST treatment (Fig. 5). In addition, our data also demonstrated that rOmpA was unable to regulate the expression of Fas and FasL in HEp-2 cells (Supplementary data Fig. S2), indicating no activation of the death receptor pathway.

rOmpA elevated mitochondrial membrane permeability in HEp-2 cells

Bcl-xL maintains normal mitochondrial permeability by in- hibiting mPTP. The opening of mPTP may destroy mitochondrial membrane integrity and thus directly collapse the normal mitochondrial membrane potential (Gyulkhandanyan et al., 2015). In the current study, we detected the mitochondrial membrane potential by staining HEp- 2 cells with TMRE. FCCP is a protonophore that depolarises mitochondria and was used as a positive control for loss of mitochondrial membrane potential and PBS was used as a negative control. Flow cytometry showed that the MFI of the positive control and the $30 \mu \mathrm{g} / \mathrm{ml} \mathrm{rOmpA}$ group were 2.58E5 and 5.96E5 whereas the MFI of the control group was 9.58E5, indicating mitochondrial membrane depolarisation and opening of $\mathrm{mPTP}$ (Fig. 6A), which has been reported to induce the release of cytochrome c and AIF (Zhang et al., 2017; Negara et al., 2018) and initiate apoptosis. Western blot showed that the $0.1 \mu \mathrm{M}$ ST group had significantly higher cytoplasmic cytochrome $\mathrm{c}$ and AIF levels compared with the other groups (Fig. 6B). The cytoplasmic cytochrome $\mathrm{c}$ and AIF levels were also significantly higher after treatment with $30 \mu \mathrm{g} / \mathrm{ml} \mathrm{rOmpA} \mathrm{com-}$ pared with controls whereas they did not differ significantly between the heat-inactivated rOmpA group and the control group (Fig. 6B). In contrast to the impact of rOmpA on cytoplasmic cytochrome $\mathrm{c}$ and AIF levels, $0.1 \mu \mathrm{M}$ ST and $30 \mu \mathrm{g} / \mathrm{ml}$ rOmpA significantly lowered mitochondrial cytochrome $c$ and AIF compared with controls (Fig. 6B). These data suggested that rOmpA induced the release of cytochrome $\mathrm{c}$ and AIF into the cytoplasm.

\section{rOmpA increased ROS and intracellular $\mathrm{Ca}^{2+}$ concentration}

Bax may cause transient mPTP opening, which promotes ROS accumulation and favors mitochondrial membrane permeabilisation. This subsequently elevates the generation of ROS and facilitates the release of cytochrome c (Birkinshaw and Czabotar, 2017). Simultaneously, mitochondria are the major source of ROS, which contribute to apoptotic cell death (Sinha et al., 2013). In this study, we evaluated ROS generation in rOmpA-treated HEp-2 cells by DCFH-DA. We found that ROS levels in the $0.1 \mu \mathrm{M}$ ST group were significantly higher than that in the control group and the differences in ROS levels between the $30 \mu \mathrm{g} / \mathrm{ml}$ rOmpA group and the con-
(A)

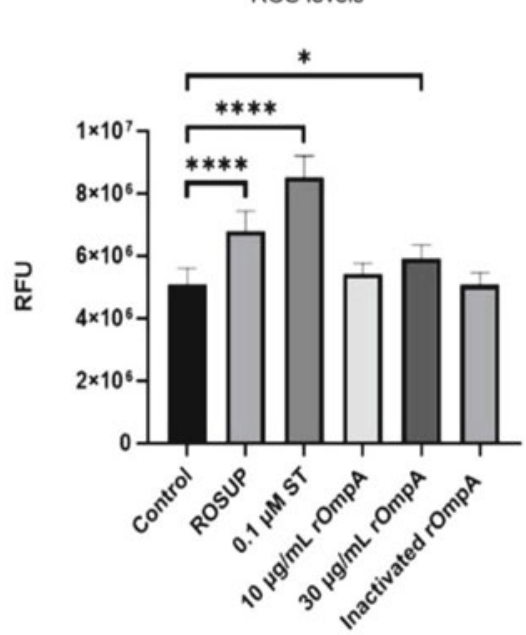

(B) Intracellular $\mathrm{Ca}^{2+}$ concentration

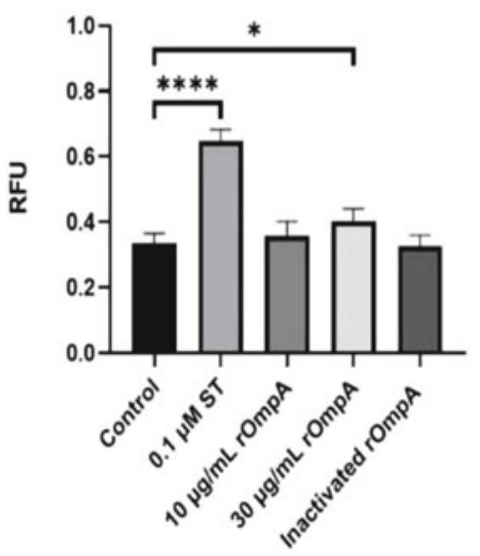

Fig. 7. Impact of rOmpA on ROS levels and intracellular $\mathrm{Ca}^{2+}$ concentrations. (A) ROS levels in HEp-2 cells after treatment with rOmpA for $8 \mathrm{~h}$. Rosup was employed as a positive control. The results are from one representative experiment of three independent experiments. (B) The $\mathrm{Ca}^{2+}$ concentrations in HEp-2 cells after treatment with rOmpA for $8 \mathrm{~h}$. The results are from one representative experiment of three independent experiments. 


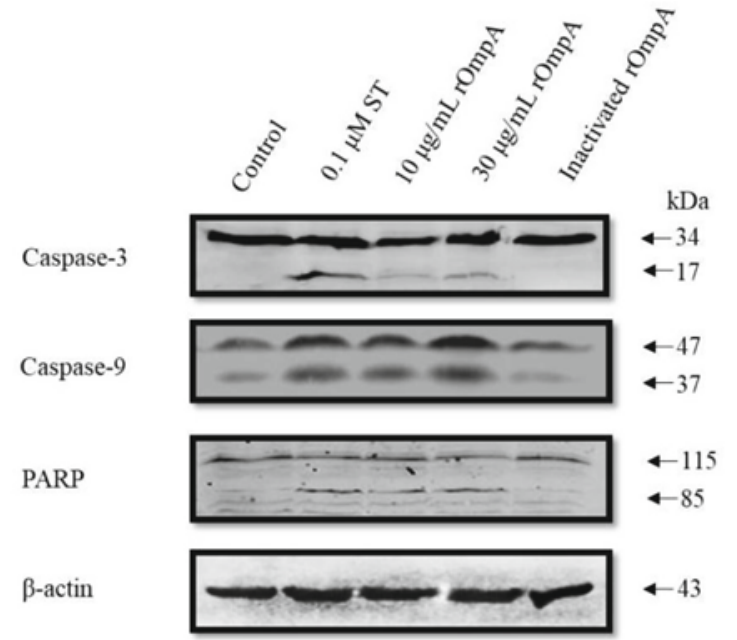

Fig. 8. Activation of caspase- 3 and caspase-9 and cleavage of PARP. HEp-2 cells were treated for $8 \mathrm{~h}$ with rOmpA. The cell lysates were resolved on $12 \%$ SDS-PAGE gels and immunoblotted with anti-caspase-3, anti-caspase- 9 and anti-PARP antibody. The results are from one representative experiment of three independent experiments.

trol group were small but statistically significant. ROS levels in the $10 \mu \mathrm{g} / \mathrm{ml} \mathrm{rOmpA}$ group and the heat-inactivated rOmpA group remained at baseline levels (Fig. 7A). These data demonstrated that rOmpA induced the increase of intracellular ROS levels. $\mathrm{Ca}^{2+}$ is one of the most versatile signals involved in the control of cellular processes and functions such as cell survival and death (Zhang et al., 2016). Wang et al. (2013) found that ROS production and intracellular $\mathrm{Ca}^{2+}$ accumulation both induced HepG2 cell apoptosis. We measured $\mathrm{Ca}^{2+}$ levels using a Fluo-3/AM fluorescent probe and observed small but significant differences after exposing HEp2 cells to $30 \mu \mathrm{g} / \mathrm{ml} \mathrm{rOmpA}$ compared with the controls, indicating that rOmpA increased $\mathrm{Ca}^{2+}$ in HEp-2 cells (Fig. 7B).

\section{rOmpA activated the caspase- 3 and caspase-9 apoptosis path- way}

The openning of mPTP results in the release of cytochrome $\mathrm{c}$ and AIF from mitochondria to the cytoplasm. Cytochrome c, dATP, Apaf-1, and procaspase-9 in the cytoplasm can form a large apoptotic body, which upon induction of apoptosis processes pro-caspase 9 into a large $(37 \mathrm{kDa})$ and a small $(10$ $\mathrm{kDa})$ subunit. Cleaved caspase- 9 can further activate downstream procaspase-3 (Liu et al., 2014; Xu et al., 2016; Li et al., $2017 \mathrm{~b}$ ), which is expressed in cells as an inactive precursor that is proteolytically generated during apoptosis. In our study, treatment with $0.1 \mu \mathrm{M}$ ST and $30 \mu \mathrm{g} / \mathrm{ml} \mathrm{rOmpA}$ showed significant caspase-9 cleavage in HEp-2 cells while exposure to $10 \mu \mathrm{g} / \mathrm{ml} \mathrm{rOmpA}$ and heat-inactivated rOmpA did not result in caspase-9 cleavage. Cleaved caspase- 3 in the $0.1 \mu \mathrm{M}$ ST group was significantly elevated compared with the other groups and similarly, cleaved caspase- 3 in the $30 \mu \mathrm{g} / \mathrm{ml} \mathrm{rOmpA}$ group was significantly higher compared with the control group (Fig. 8). Poly ADP-ribose polymerases (PARP) are a group of proteins present in most eukaryotic cells. The posttranslational modification enzyme PARP-1 is an important substrate for caspase-3. When apoptosis occurs, PARP-1 is inhibited by caspase-3, leading to the cleavage of PARP (Wang et al., 2011; Galia et al., 2012). In our study, we found an incease in the active forms of both molecules in the $0.1 \mu \mathrm{M}$ ST group and the $30 \mu \mathrm{g} / \mathrm{ml} \mathrm{rOmpA}$ group, resulting in the cleavage of PARP (Fig. 8). In summary, rOmpA stimulated the activation of caspase- 9 and caspase- 3 apoptosis pathway in HEp-2 cells.

\section{Discussion}

Our study revealed a new understanding of the molecular mechanism of S. maltophilia OmpA on the induction of apoptosis in HEp-2 cells. OmpA is the main outer membrane protein of Gram-negative bacteria, which maintains the integrity of bacterial outer membrane structure and normal inheritance of bacterial morphology (Confer and Ayalew, 2013). OmpA is also a bridge between bacteria and host, being of great significance during bacterial infections and the subsequent host immune resistance (Smith et al., 2007). Choi et al. (2005) reported that OmpA directly adheres and invades the host cells and thus leads to cell apoptosis through the destruction of the nucleus and mitochondria. Acinetobacter baumannii OmpA adheres to HeLa cells and induces autophagy in HeLa cells (An et al., 2019) and OmpA knockdown strains have decreased ability to replicate and adhere to host cells both in vitro and in vivo (Gaddy et al., 2009). In agreement with these studies, we found that rOmpA adhered to HEp- 2 cells. Studies have found that bacterial outer membrane vesicles mediate delivery of OmpA to enter host cells, which are spontaneously released by Gram-negative bacteria (Gnopo et al., 2020; Mancini et al., 2020). However, the mechanism by which S. maltophilia OmpA enters the host cell is unclear and is a target for future studies.

The typical ultrastructural changes of apoptotic cells include the decrease or disappearance of villi on the cell surface, the shrinkage of the nuclear membrane, the decrease of nuclear volume, chromatin aggregation, and appearance of vacuoles in the cytoplasm (Atale et al., 2014). To determine whether the purified rOmpA was biologically active, we first observed the morphological and nucleus changes of HEp-2 cells after stimulation with $30 \mu \mathrm{g} / \mathrm{ml} \mathrm{rOmpA}$ and detected nucleus roundness, pyknosis and chromatin aggregation. These results were consistent with the characteristics of apoptosis and rOmpAinduced cell apoptosis was further confirmed by annexin V/PI. Taken together, these data indicated that $30 \mu \mathrm{g} / \mathrm{ml} \mathrm{rOmpA}$ induced apoptosis of HEp-2 cells.

The group of proteins known as Bcl-2 family members are the central players of apoptosis (Renault et al., 2016). The proapoptotic protein Bax induces cell death via mitochondrial membrane permeabilisation that leads to the release of small proapoptotic molecules such as cytochrome c. However, Bax can be inhibited by the overexpression of the pro-survival proteins $\mathrm{Bcl}-2$ and $\mathrm{Bcl}-\mathrm{xL}$. Bcl-xL is an important member of the Bcl-2 family and its reduction further promotes mPTP opening and increased mitochondrial membrane permeability (Kim, 2005). We found that $30 \mu \mathrm{g} / \mathrm{ml} \mathrm{rOmpA}$ caused upregulation of Bax and downregulation of Bcl-xL. We also observed that the depolarisation of mitochondrial memb- 
rane potential in HEp-2 cells was stimulated by exposure to $30 \mu \mathrm{g} / \mathrm{ml} \mathrm{rOmpA}$. With the increase of mitochondrial membrane permeability, cytochrome $\mathrm{c}$ and AIF were released to the cytoplasm from mitochondria (Morris et al., 2018). After released into the cytoplasm, cytochrome $\mathrm{c}$ binds to apoptotic protease activating facter-1 (Apaf-1) and procaspase-9, initiating apoptosis (Kang et al., 2018). Rumbo et al. (2014) found that Acinetobacter baumannii OmpA localises to the mitochondria and induces apoptosis of epithelial cells by releasing cytochrome $c$ and AIF. In our present stduy, the protein levels of cytoplasmic cytochrome $\mathrm{c}$ and AIF were opposite to those in mitochondria, indicating that cytochrome $\mathrm{c}$ and AIF were released into the cytosol as a consequence of mitochondrial disintegation, which was consistent with the features of the mitochondrial apoptotic pathway. It has been described that increased mitochondrial permeability dissipates the proton electrochemical gradient, leading to ATP depletion and further ROS production (Sinha et al., 2013). Furthermore, ROS generation has a strong influence the mPTP opening (Zhang et al., 2016). In our study, we demonstrated that rOmpA induced the production of ROS in HEp2 cells. Intracellular calcium $\mathrm{Ca}^{2+}$ is a critical second messenger and regulator of cell apoptosis (Meng et al., 2014). The increase of $\mathrm{Ca}^{2+}$ concentration favours ROS generation and promotes the opening of MPTP. We showed that 30 $\mu \mathrm{g} / \mathrm{ml} \mathrm{rOmpA}$ induced the production of ROS and increased the intracellular $\mathrm{Ca}^{2+}$ concentration in HEp-2 cells. PARP-1 is a substrate for caspase- 3 activation and PARP is normally cleaved by caspases during apoptosis. Caspase- 3 is a cysteine protease with aspartic specificity and a well-characterised effector of apoptosis signalling (Cregan et al., 2004). This study demonstrated that $30 \mu \mathrm{g} / \mathrm{ml}$ rOmpA induced cleavage of caspase-9, caspase- 3 , and PARP. These findings confirmed that rOmpA sequentially activated caspase- 9 and caspase- 3 , which are main components of the mitochondrial apoptosis pathway.

In summary, the findings of the present study indicated that S. maltophilia OmpA was a virulence factor that adhered to epithelial cells and induced cell death by the mitochondrial apoptotic pathway. OmpA regulated Bax and Bcl-xL protein expression and promoted the release of pro-apoptotic molecules such as cytochrome $\mathrm{c}$ and AIF. Apoptosis of epithelial cells may allow the bacteria to access the deeper tissues in the lung. We provide improved elucidation of the pathogenic role of $S$. maltophilia OmpA in apoptosis.

\section{Acknowledgments}

This work was supported by the National Natural Science Foundation of China $(81571959,81071399)$. The funder had no role in study design, data collectionand analysis, decision to publish, or preparation of the manuscript.

\section{Conflict of Interest}

The authors declare that they have no competing interests.

\section{References}

An, Z., Huang, X., Zheng, C., and Ding, W. 2019. Acinetobacter baumannii outer membrane protein A induces HeLa cell autophagy via MAPK/JNK signaling pathway. Int. J. Med. Microbiol. 309, 97-107.

Atale, N., Gupta, S., Yadav, U.C.S., and Rani, V. 2014. Cell-death assessment by fluorescent and nonfluorescent cytosolic and nuclear staining techniques. J. Microsc. 225, 7-19.

Birkinshaw, R.W. and Czabotar, P.E. 2017. The Bcl-2 family of proteins and mitochondrial outer membrane permeabilisation. Semin. Cell Dev. Biol. 72, 152-162.

Chang, Y.T., Lin, C.Y., Lu, P.L., Lai, C.C., Chen, T.C., Chen, C.Y., Wu, D.C., Wang, T.P., Lin, C.M., Wang, T.P., et al. 2012. Stenotrophomonas maltophilia blood stream infection: comparison between community onset and hospital-acquired infections. $J$. Microbiol. Immunol. Infect. 47, 28-35.

Choi, C.C., Hyun, S.H., Lee, J.Y., Lee, J.S., Lee, Y.S., Kim, S.A., Chae, J.P., Yoo, S.M., and Lee, J.C. 2008. Acinetobacter baumannii outer membrane protein A targets the nucleus and induces cytotoxicity. Cell. Microbiol. 10, 309-319.

Choi, C.C., Lee, E.Y., Lee, Y.C., Park, T.I., Kim, H.J., Hyun, S.H., Kim, S.A., Lee, S.K., and Lee, J.C. 2005. Outer membrane protein 38 of Acinetobacter baumannii localizes to the mitochondria and induces apoptosis of epithelial cells. Cell. Microbiol. 7, 11271138 .

Confer, A.W. and Ayalew, S. 2013. The OmpA family of proteins: roles in bacterial pathogenesis and immunity. Vet. Microbiol. 163, 207-222.

Cregan, S.P., Dawson, V.L., and Slack, R.S. 2004. Role of AIF in caspase-dependent and caspase-independent cell death. Oncogene 23, 2785-2796.

Elmore, S. 2007. Apoptosis:a review of programmed cell death. Toxicol. Pathol. 35, 495-516.

Gaddy, J.A., Tomaras, A.P., and Luis, A.A. 2009. The Acinetobacter baumannii 19606 OmpA protein plays a role in biofilm formation on abiotic surfaces and in the interaction of this pathogen with eukaryotic cells. Infect. Immun. 77, 3150-3160.

Galia, A., Calogero, A.E., Condorelli, R.A., Fraggetta, F., La Corte, C., Ridolfo, F., Bosco, P., Castiglione, R., and Salemi, M. 2012. PARP-1 protein expression in glioblastoma multiforme. Eur. J. Histochem. 56, e9.

Gnopo, Y.M.D., Mirsa, A., Hsu, H.L., DeLisa, M.P., Daniel, S., and Putnam, D. 2020. Induced fusion and aggregation of bacterial outer membrane vesicles: experimental and theoretical analysis. J. Colloid Interf. Sci. 578, 522-532.

Gyulkhandanyan, A.V., Mutlu, A., Freedman, J., and Leytin, V. 2015. Mitochondrial permeability transition pore (MPTP)-dependent and -independent pathways of mitochondrial membrane depolarization, cell shrinkage and microparticle formation during platelet apoptosis. Br. J. Haematol. 169, 142-145.

Henry, C.M., Hollville, E., and Martin, S.J. 2013. Measuring apoptosis by microscopy and flow cytometry. Methods 61, 90-97.

Kang, Y., Sun, Y., Zhang, Y., and Wang, Z. 2018. Cytochrome $c$ is important in apoptosis of labial glands in primary Sjogren's syndrome. Mol. Med. Rep. 17, 1993-1997.

Kim, R. 2005. Unknotting the roles of Bcl-2 and Bcl-xL. Biochem. Biophys. Res. Commun. 333, 336-343.

Lee, J.S., Choi, C.H., Kim, J.W., and Lee, J.C. 2010. Acinetobacter baumannii outer membrane protein A induces dendritic cell death through mitochondrial targeting. J. Microbiol. 48, 387-392.

Lee, M.R., Wang, H.C., Yang, C.Y., Lin, C.K., Kuo, H.Y., Ko, J.C., Sheng, W.H., Lee, L.N., Yu, C.J., and Hsueh, P.R. 2014. Clinical characteristics and outcomes of patients with pleural infections due to Stenotrophomonas maltophilia at a medical center in Taiwan, 2004-2012. Eur. J. Clin. Microbiol. Infect. Dis. 33, 1143-1148. 
Li, Y., Tang, X., Zhao, Z., Wang, H., Wang, X., Shang, X., Liu, P., Kou, Z., Jiang, Y., and Li, Y. 2019. Intranasal immunization with recombinant outer membrane protein A induces protective immune response against S. maltophilia infection. PLOS ONE 14, e0214596.

Li, Y., Zhao, Z.Q., Liu, P., Shang, X.Y., Tang, X.P., and Li, Y. 2017 a. Bioinformatics analysis of Stenotrophomonas maltophilia outer membrane protein OmpA. Mil. Med. Sci. 41, 987-990.

Li, P., Zhou, L., Zhao, T., Liu, X., Zhang, P., Liu, Y., Zheng, X., and Li, Q. 2017b. Caspase-9: structure, mechanisms and clinical application. Oncotarget. 8, 23996-24008.

Liu, J., Yao, Y., Ding, H., and Chen, R. 2014. Oxymatrine triggers apoptosis by regulating $\mathrm{Bcl}-2$ family proteins and activating caspase-3/caspase-9 pathway in human leukemia HL-60 cells. Tumour Biol. 35, 5409-5415.

Lopes, B.R.P., Ribeiro, A.G., Silva, T.F., Barbosa, L.V., Jesus, T.I., Matsuda, B.K., Costa, M.F., and Toledo, K.A. 2020. Diagnosis and treatment of HEp-2 cells contaminated with mycoplasma. Braz. J. Biol. Epub Apr. 22.

Mancini, F., Rossi, O., Necchi, F., and Micoli, F. 2020. OMV vaccines and the role of TLR agonists in immune response. Int. J. Mol. Sci. 21, 4416.

March, C., Moranta, D., Regueiro, V., Llobet, E., Tomás, A., Garmendia, J., and Bengoechea, J.A. 2011. Klebsiella pneumoniae outer membrane protein $\mathrm{A}$ is required to prevent the activation of airway epithelial cells. J. Biol. Chem. 286, 9956-9967.

Meng, G., Pan, L., Li, C., Hu, F., Shi, X., Lee, I., Drevenšek-Olenik, I., Zhang, X., and Xua, J. 2014. Temperature-induced labelling of Fluo-3 AM selectively yields brighter nucleus in adherent cells. Biochem. Biophys. Res. Commun. 443, 888-893.

Morris, G., Walker, A.J., Berk, M., Maes, M., and Puri, B.K. 2018. Cell death pathways: a novel therapeutic approach for neuroscientists. Mol. Neurobiol. 55, 5767-5786.

Namba, A., Mano, N., Takano, H., Beppu, T., Ueda, K., and Hirose, H. 2008. OmpA is an adhesion factor of Aeromonas veronii, an optimistic pathogen that habituates in carp intestinal tract. J. Appl. Microbiol. 105, 1441-1451.

Negara, K.S., Suwiyoga, K., Pemayun, T.G.A., Sudewi, A.A.R., Astawa, N.M., Arijana, I.G.N.K., and Tunas, K. 2018. The role of caspase-3, apoptosis-inducing factor, and B-cell lymphoma-2 expressions in term premature rupture of membrane. Rev. Bras. Ginecol. Obstet. 40, 733-739.

Pistritto, G., Trisciuoglio, D., Ceci, C., Garufi, A., and D'Orazi, G. 2016. Apoptosis as anticancer mechanism: function and dysfunction of its modulators and targeted therapeutic strategies. Aging 8, 603-619.

Renault, T.T., Dejean, L.M., and Manon, S. 2016. A brewing understanding of the regulation of Bax function by Bcl-xL and Bcl-2. Mech. Ageing Dev. 161, 201-210.

Rumbo, C., Tomás, M., Moreira, E.F., Soares, N.C., Carvajal, M., Santillana, E., Beceiro, A., Romero, A., and Bou, G. 2014. The Acinetobacter baumannii Omp33-36 porin is a virulence factor that induces apoptosis and modulates autophagy in human cells. Infect. Immun. 82, 4666-4680.
Shin, S., Lu, G., Cai, M., and Kim K.S. 2005. Escherichia coli outer membrane protein A adheres to human brain microvascular endothelial cells. Biochem. Biophys. Res. Commun. 330, 1199-1204.

Siegel, S.J. and Weiser, J.N. 2015. Mechanisms of bacterial colonization of the respiratory tract. Annu. Rev. Microbiol. 69, 425-444.

Sinha, K., Das, J., Pal, P.P., and Sil, P.C. 2013. Oxidative stress: the mitochondria-dependent and mitochondria-independent pathways of apoptosis. Arch. Toxicol. 87, 1157-1180.

Smith, S.G.J., Mahon, M., Lambert, M.A., and Fagan, R.P. 2007. A molecular Swiss army knife: OmpA structure, function and expression. FEMS Microbiol. Lett. 273, 1-11.

Sukumaran, S.K., Selvaraj, S.K., and Prasadarao, N.V. 2004. Inhibition of apoptosis by Escherichia coli $\mathrm{K} 1$ is accompanied by increased expression of Bcl-xL and blockade of mitochondrial cytochrome c release in macrophages. Infect. Immun. 72, 6012-6022.

Wallberg, F., Tenev, T., and Meier, P. 2016. Analysis of apoptosis and necroptosis by fluorescence-activated cell sorting. Cold Spring Harb. Protoc. 2016, 347-352.

Wang, Y., Kim, N.S., Haince, J.F., Kang, H.C., David, K.K., Andrabi, S.A., Poirier, G.G., Dawson, V.L., and Dawson, T.M. 2011. Poly (ADP-ribose) (PAR) binding to apoptosis-inducing factor is critical for PAR Polymerase-1-dependent cell death (parthanatos). Sci. Signal. 4, ra20.

Wang, C., Liu, C., Niu, L., Wang, L., Hou, L., and Cao, X. 2013. Surfactin-induced apoptosis through ROS-ERS-Ca ${ }^{2+}$-ERK pathways in HepG2 cells. Cell Biochem. Biophys. 67, 1433-1439.

Wu, B.T, Bao, L., Sun, Z., Li, D.K., and Zhang, Y. 2011. The OmpAlike protein Loa22 from Leptospira interrogans serovar lai induces apoptosis in A549 via $\mathrm{Ca}^{2+}$ signal pathway. J. Sichuan Univ. Med. Sci. Edn. 42, 298-302.

Xu, W., Guo, G., Li, J., Ding, Z., Sheng, J., Li, J., and Tan, W. 2016. Activation of Bcl-2-caspase-9 apoptosis pathway in the testis of asthmatic mice. PLoS ONE 11, e0149353.

Xu, G., Tang, X., Shang, X., Li, Y., Wang, J., Yue, J., and Li, Y. 2018. Identification of immunogenic outer membrane proteins and evaluation of their protective efficacy against Stenotrophomonas maltophilia. BMC Infect. Dis. 18, 347.

Zhang, Y., Bao, L., Zhu, H., Huang, B., and Zhang, H. 2010. OmpAlike protein Loa 22 from Leptospira interogans serovar Lai is cytotoxic to cultured rat renal cells and promotes inflammatory responses. Acta Biochim. Biophys. Sin. 42, 70-79.

Zhang, J., Wang, X., Vikash, V., Ye, Q., Wu, D., Liu, Y., and Dong, W. 2016. ROS and ROS-mediated cellular signaling. Oxid. Med. Cell. Longev. 2016, 4350965.

Zhang, M., Zheng, J., Nussinov, R., and Ma, B. 2017. Release of cytochrome $\mathrm{c}$ from Bax pores at the mitochondrial membrane. Sci. Rep. 7, 2635.

Zhao, X., Tao, X., Xu, L., Yin, L., Qi, Y., Xu, Y., Han, X., and Peng, J. 2016. Dioscin induces apoptosis in human cervical carcinoma $\mathrm{HeLa}$ and SiHa cells through ROS-mediated DNA damage and the mitochondrial signaling pathway. Molecules 21, 730.

Zhou, F., Yang, Y., and Xing, D. 2011. Bcl-2 and Bcl-xL play important roles in the crosstalk between autophagy and apoptosis. FEBS J. 278, 403-413. 